\title{
Feeding the Rural Tourism Strategy? Food and Notions of Place and Identity
}

\author{
GODFREY BALDACCHINO ${ }^{*, * *, \dagger}$ \\ *Department of Sociology, University of Malta, Msida MSD, Malta, **Island Studies Teaching Fellow, \\ University of Prince Edward Island, Charlottetown, Canada, and "Visiting Professor of Island Tourism, \\ Università di Corsica Pascal Paoli, Corte, France
}

\begin{abstract}
The humble rural cuisine has now been thrust at the forefront of economic development strategies. This conceptual paper is a contribution to a growing critical awareness of the operations of the food industry and helps to foster a critical understanding of how, if at all, local food and its associated culture can help sustain rural tourism particularly and rural communities generally. It is inspired by literature about the international political economy of food and the many experiences of local food development, and is aware of the contrast between the structure of the industry and the hopes associated with its practice on the ground. The paper thus argues that, beyond the glamour and hype, there are those who gain, as well as those who lose, from the current food fad. While it explains the causes of the contemporary craze with food, the paper also interrogates the naive expectations often placed in food as a motor of rural development, and as the panacea for struggling rural communities. The empirical data on which this chapter is based are drawn from 18 short chapters explaining the history of various "traditional dishes" from the islands of the broad North Atlantic that feature in a recent food publication.
\end{abstract}

KEY WORDS: authenticity, islands, local food, North Atlantic, power, privilege, rural development, taste, tourism

\section{Introduction}

Consider the case of Smakbyn (the "taste village") in the vicinity of medieval Kastelholm castle, in the Alland Islands (population: 27,000). This is a recent, aggressive investment focusing on Åland food and drink traditions, seeking to attract tourist visitors as well as tap into various market segments outside Alland. It has been set up and is owned by Åland's internationally well-known chief, Michael Björklund (he has been chosen chef-of-the-year both in Sweden and in Finland). His company introduces new and innovative ways of combining local competence and food resources with the growing interest in lifestyle, locally produced food and drink, as well as within the international tourist business. This project has secured significant funding 
support from the European Union's rural development programme in Åland for 20092013 (Welcome to Smakbyn!, 2014).

There are many similar Smakbyns in operation, or taking shape, around the world today. They seek to tap into a love affair that contemporary Western society has developed with food: a romancing of a basic need into a series of dishes that are associated with national identity and thus become ersatz cultural icons that hope to serve cultural and political functions beyond the obvious and mundane one of assuaging hunger (Raviv, 2003). Food is increasingly finding its rightful place at the table of a considerable range of touristic and scholarly feasts. And while food has always been an integral part of tourism, we can now speak explicitly about food tourism. Perhaps in contrast to earlier decades, many contemporary tourists seem especially keen and adventurous enough to locate and sample local fare; part of a growing appreciation of "experiential consumption" in tourism (Holbrook \& Hirschman, 1982). They are also willing to support and participate in a democratisation of food traditions, indulging in food (and drink) items and recipes that purport such humble and common origins that inspire authenticity and popularity (Cohen \& Avieli, 2004).

\section{This Paper}

Breaking bread together is perhaps the oldest form of hospitality and trust. Food encounters connect locals with visitors, with members of the diaspora and with absolute strangers; while lingering, rediscovered or invented recipes provide economic lifelines, and new markets, to local produce.

The paper reviews the main instigators towards the current emergence of food as national symbol; addresses the key limitations to the naïve usage of food (and drink) as platforms in rural development strategies and finally comments about the specificities of food traditions from islands in the broad North Atlantic. While the local food industry is being embraced by many tourism destinations as an opportunity to wider their tourism appeal while showcasing and supporting local produce, this paper grounds this analysis within a more structural, macro framework that takes into consideration the workings of the global food industry. The fun and fascination of serving a local dish as part of a rural tourism strategy must thus be seen in light of the surrounding power and privilege. The paper explains the causes of the contemporary craze with local food, and criticises the hopes often placed in food as an apolitical motor of rural and small island development.

\section{Method}

The background to this paper is A Taste of Islands, a book project, conceived and executed by my wife Anna (a great cook) and I (a grateful eater of her cooking) as coeditors (Baldacchino \& Baldacchino, 2012). We wanted to pitch a text at an audience that straddled those interested in food and cooking with those interested in islands and island life and history. Thus we came up with a publication that offered, in each chapter, the standard information found in recipe books - a colour photo of a "traditional" island dish, plus ingredients and method of preparation - but accompanied with an "essay", an anthropological window to the origins and transformations of each dish. 
In this way, we provided a "taste" of islands, both via the dish itself and the historical narrative that comes along with it.

The book ended up with 60 different chapters. Most were volunteered following a call for expressions of interest circulated via a number of list-serves associated with the study of islands. Eighteen of these eventual chapters dealt with dishes sourced from the islands of the broad North Atlantic, and written mainly by local scholars. The chapters comprise three soups (Fish Ball Soup from Streymoy, Faroe Islands; Fish Chowder from Prince Edward Island, Canada and Halibut Soup from Greenland); five light snacks (Black Butter from Jersey, British Isles; Boxty Pancakes from Ireland; Filled Potato Dumplings from Oland, Sweden; Flat Bread and Mutton Paté from Iceland and Spicy Pickled Herring on Rye Bread from Bornholm, Denmark); four main courses (Jigg's Dinner from Newfoundland, Canada; Lobster Scallop Newberg from Little Cranberry Island, Maine, USA; Over-Baked Flatfish on Reeds from Saaremaa, Estonia and Rock Crab from Heligoland, Germany) and finally six desserts (Åland Pancake from Åland, Finland; Bakewell Pudding from Great Britain; Guernsey Fruit Loaf from Guernsey, British Isles; Roe Pancakes from Vega, Norway; Seal Fat Fried Donuts from the Iles de la Madeleine, Quebec, Canada and Saffron Pancake from Gotland, Sweden). This paper draws upon the content of these chapters as its data collection of empirical findings.

The research method adopted here is one of deliberate juxtaposition. Inspired by Boon (2007), the content of these chapters is first analysed as symptomatic of the front-of-house operations of the food component of contemporary rural tourism; nuanced and romanticised by a discourse that celebrates locality, history and authenticity, and the only discourse that finds its way into food books. This analysis is then contrasted with the more distant, back-of-house but just-as-real operations of the notalways-local food industry that cleverly positions itself to tap into this emerging market. Reminiscent of Marx and his analysis in Grundrisse (1959/1973), the exclusive foregrounding of the sphere of (food) consumption deflects an awareness of the spheres of (food) production, distribution and exchange.

The next section reviews the characteristics of traditional food, its ingredients and recipes, from the broad North Atlantic, emergent from the empirical data. The focus is on the cultural influence of climate and topography on cuisine; the perennial struggle for survival; the inevitable connectivities of island societies via trade, invasion or migration; the ensuing hybridity of their traditions even in kitchens and the development of foods that act as markers of social hierarchy and status.

\section{North Atlantic Food: Some Glocal Trends}

One characteristic pattern of narrating food stories from the broad North Atlantic is to solicit the weather as a protagonist, even as an all-powerful despot. Harsh, cold and unpredictable climates with unforgiving long and dark winters, along with possibly poor soils and short farming seasons, are the backdrop to the emergence of a rugged, tough and tested people used to eating very simple and basic food, and of being ever open and adaptable to the prevailing weather conditions: the Faroes, for example, are often referred to as the Land of Maybe: 
Maybe we will go fishing tomorrow, maybe we will not; maybe we will have a wedding tomorrow; maybe we will not. (Bogadottir, 2012, p. 14)

The original recipe for Icelandic flatbread, known as flatbraud or flatkökur, "could not be simpler: just rye and water... sometimes supplemented with Iceland moss" (Jónsson, 2012, p. 62).

In such frugal circumstances, with life and death ever in the balance, nothing can be allowed to go to waste. Not only that, but there is an almost morbid and exotic reversal of some offerings of such frugality and scarcity into prized and coveted items of consumption. From the repertoire of Greenlandic dishes, which includes seals, whales, fish, birds, musk oxen, hares and caribou,

Everything ... is eaten, including their bone marrow and entrails ... It is also a delicacy to eat a sort of pudding made with seal blood. (Olsen, 2012, pp. 28-29)

Frugality and simplicity are ubiquitous with poor families in harsh environments. Hard tack, or ship's biscuit, the typical accompaniment to cod in Newfoundland, was made from flour, water and sometimes salt (Springuel, 2011). It was not just inexpensive but long-lasting.

In situations of abject poverty, staple foods had to last longer. In Ireland, we are told that potatoes

would frequently be only partly cooked, leaving a hard core of potato known as the "moon" or "bone" intact. The effect was to provide a feeling of fullness for longer, as the partially cooked centres took longer to digest. (Stephens, 2012, p. 50)

It may be difficult to imagine living in societies where what we may consider to be staple ingredients in our cuisine are tellingly absent, and for long stretches of time. For many centuries, for example, "the key characteristic of Icelandic food culture ... was the wide-ranging shortage of salt" (Jónsson, 2012, p. 62).

A second characteristic of traditional food from North Atlantic islands is their association with histories of trade, settlement, invasion, occupation, colonialism or just fortuitous encounter. Islands are typically crossroads and interfaces of different cultures, materials and peoples; they have also often been the targets for regional or imperial ambitions, and their foods and recipes often bear testimony to different layers of influence. While it is probably true that history is written by the victors and not the vanquished, recipes may be written by both. On Canada's Prince Edward Island, seafood chowder is a mélange that traces its origins also to the early French Acadian settlers, forcefully expelled by the British in the 1750s. The word "chowder" itself probably originates from the French chaudrière, a heating pot (Sutton, 2012, p. 20). In the Vega archipelago of Northern Norway, a brisk trade in stockfish and roe with Western Europe - and particularly during the 40 days of Lent, when eating meat was forbidden - took off after the shipwreck of a Venetian trader, Pietro Querini, in 1432 (Griggio, 2012, p. 251). 
Third, eating habits also provide insights into class structure and social inequality. Even today, not everyone can afford certain ingredients or meals, or afford them regularly, and this distinction remains a common mark of prestige and affluence. Judgements of taste are not just consequences of social rank and purchasing power, but are themselves acts that determine social positioning (Bourdieu, 1984). In Newfoundland, inexpensive salt beef was all that large fishing families could afford (Tye, 2012, p. 137). The Åland pancake includes cardamom as a spice, an exotic import, for those who could afford it (Griessner, 2012, p. 227). Moreover, items that have long been considered as basic fare for the poor have staged a remarkable transformation and status reversal: as with the Heligoland rock crab (knieper) and the Maine lobster, now both highly prized (Ratter, 2012; Thomas, 2012).

Fourth, eating habits are also a function of very specific criteria, including the local availability of certain products; and, with the arrival of global food and its habits, this exoticisation of place- and culture-based products is now seen as an important marker of locality, and of associated representations of what is proper and acceptable. The North Atlantic has its own share of such cultural collisions. The exceptional repertoire of food from Greenland (referred to above) is one example of this; another is the croxignoles (doughnuts) fried in seal fat, a characteristic of the Magdalene Islands, in Quebec, Canada (Tita, Theriault, \& Langford, 2012). These distinctions mark the rather thin line between what is considered disgusting and delicious (Korsmeyer, 2002). This is not only about plural notions of what is pleasant to the eye as much as to the palate - think, for example, about the mixed opinions about rabbit as pet, pest or food - but also about trade wars, aboriginal peoples' rights and the international political economy of what is deemed appropriate to hunt and consume, implicitly boosting certain "food regimes" and weakening others (Friedmann, 1993). These tastes also implicitly protect certain species from human consumption but not others: in the North Atlantic, think harp seals hunted by Canadians, pilot whales hunted by the Faroese and fin whales hunted by Icelanders (Barry, 2005; Fielding, 2010; Parsons \& Rawles, 2003).

All interesting details, agreed, but perhaps not enough to elevate these factoids into a gripping cultural industry and a growing worldwide development in rural tourism. How can we explain our current obsession with food, and its increasingly central role in the experience economy?

\section{Tasty Offerings}

Food is undergoing a cultural renaissance: chefs, restaurants, recipes and dishes are today serious conversation pieces. Not only has food, and its preparation and consumption, turned into a high art form for the savvy and literati, but it has also become a key marker of both the exceptionality of and connectivity between living cultures and the places which become meaningful as repositories of such cultural practices. Placebased initiatives, from the specifics of tourism to the generics of branding, will evoke food as a central component of identity and memory (Sutton, 2001; Tellström, Gustafsson, \& Mossberg, 2006).

Eating is the basic need for all living things, so much so that many living things spend most of their time eating; simple organisms spend all their lives eating. And, 
as far as homo sapiens is concerned, the poorer the people are, the larger the proportion of their income and life concerns is dedicated to survival needs, of which eating and drinking are, well, vital. Moreover, the process of ingestion, what happens directly during eating, is fairly basic and universal, and not subject to much interest or exploration. As a recent book suggests, men and women everywhere

ingest nutrients. They grind and sculpt them into a moistened bolus that is delivered, via ... sequential contractions, into a self-kneading sack of hydrochloric acid and then dumped into a tubular leach field, where it is converted into the most powerful taboo in human history. (Roach, 2013, p. 1)

Granted, eating may be the opening act of a crucial biochemical process. But, it is also the closing act of a millenary anthropological and sociological practice. Meals have long served as events for the reproduction and reinforcement of social relations and social status (Cohen \& Avieli, 2004). But, the act of eating is today elevated to much higher levels than the social, necessary or mundane. It is being repackaged as a culinary experience, an affirmation of history and heritage, a nostalgic link with the past, a key medium for rich cultural encounters between hosts and guests, an opportunity for playful kitchen experimentation and an economic opportunity for peripheral regions. And amid all of this, it remains an intrinsic facet of power and privilege.

In a way, it is strange that it should be so. As we are reminded, ours is the "cooking paradox" generation: so many people today read about cooking or watch cookery programmes, reality shows, soaps and contests on television (Chef! in the UK in the 1990s; and Hell's Kitchen and Master Chef in the USA in more recent years), or even movies about cooks (Tucci, Powell, Child, \& Prud'homme, 2010). Meanwhile, and in spite of this vogue, never in human history have so many people spent so little time preparing food from scratch as now (Pollan, 2013).

\section{What's Cooking? Explaining the Food Craze}

Each place is unique; and yet, there is a pattern within this global diversity. Owe Ronström, a cultural anthropologist, offers an explanation as to why this craze with food (and also with islands). He muses about how, for example, saffron pancake has been produced and presented as a "typical dessert" from the island of Gotland, Sweden, during the last three or four decades; how it is offered and portrayed as traditional, old, archaic, locally distinctive and even endemic. Yet, from his childhood in the 1950s, Ronström admits that he cannot remember having heard about the saffron pancake; nor can he remember any instance when saffron pancake was served. And, to his parents, as to many other Gotlanders of their generation, saffron pancake was an oddity up to at least the 1970 s, when the victorious advance of the dish as typically Gotlandic seems to have begun (Ronström, 2012).

This is the story of many so-called traditional dishes, and other recent practices and manifestations of the invention of heritage and its status elevation. A similar story has sprung around Smalahove, a "peculiar relic of Nordic gastronomy" - salted, smoked and cooked sheep's head - that has become part of destination branding of Voss, in West Norway (Gyimóthy \& Mykletun, 2009). Quite similarly, the so-called "Icelandic 
sweater" has assumed iconic status, particularly in times of crisis, when attention has shifted to the image and identity of the Icelandic nation. Yet, it is an invented tradition, dating back only to the mid-twentieth century, and which is not necessarily made in Iceland or from indigenous wool (Helgadottir, 2011, p. 66). And the humble potato, Solanum tuberosum, now part of the national dish of many European countries including Austria, Belarus, Britain, Estonia, Germany, Ireland, Lithuania and Sweden (Gutsy Gourmet, 2013) - only started being imported into Europe from South America (via the Canary Islands and Spain) after 1532 CE (Hawkes \& Francisco-Ortega, 1993). One of the earliest references to the potato in Sweden, for example, is to its planting in a botanical garden in Uppsala, as late as 1658 (Malm, 2012, p. 58). Of course, had the potato arrived in Europe much more recently, its introduction may have been blocked, being labelled as an invasive species. Indeed, the European Union's 2020 Biodiversity Strategy, adopted in May 2011, includes a dedicated legislative instrument on invasive alien species (European Commission, 2012).

Ronström (2012) goes on to explain how this general obsession with food, and the specific transition of the pancake to central cultural icon, has come about. The analysis in the following is based largely on his reflections, but it also examines the issue from a slightly different and more expansive angle.

The first culprit for the current food obsession, as posited by Ronström (2012, p. 255), is glocalisation, "when the locally distinctive is produced and formatted to meet global standards". This is one of the widespread responses to the threat of globalisation: while we witness a widespread wave of standardisation in socio-economic practices around the world - in the way we dress, what languages we speak, what protocols we follow - this "sea of sameness" dynamic has generated a greater appreciation for diversity and differentiation. Many globalising processes - such as tourism and information technology - are now paradoxically used to facilitate experiences and encounters with what is different and resilient. In many countries, this has involved an intensification of heritage production; a recognition of exceptional materials and cultures (as with those inscribed on the UNESCO World Heritage List) and a multiplication of authenticities provided from exclusive locations. An important component of this package is a series of up-scale restaurants serving local food and local drinks. In Gotland, for example, a standard menu of such restaurants now consists of soup from kajp (wild leek) or ramslök (bears garlic, or buckrams, that grow wild all over the island), lamb steak and, of course, saffron pancake.

Second is a focus on smaller scale in contemporary conceptualisations of place. In the early twentieth century, the Western world was engulfed in a wave of nationalism that eventually led to the break-up of empires, a process that gathered momentum in the period of rampant decolonisation of 1944-1984. But, that wave has now been followed by a fresh and countervailing impetus of regionalisation, whereby - with states firmly ensconced in their status - citizens are affirming an identity that is not national but much more local and intimate, gravitating towards smaller scale representations of place. Some of these expressions of ethno-nationalism and regionalism have led to requests for secession and autonomy, as much as to a proliferation of local government and governance; but, beyond the political, they have certainly convulsed the nature of the representation and referencing of the local. 
Just as "the nation state" has been ascribed with much of the ideas, narratives, symbols and paraphernalia that justify its existence as a state - what is still a work in progress in various ex-colonial jurisdictions - in much the same way, a distinct signature - involving history, heroes, folk music, costumes, customs, dialects, flora and fauna, as much as food and drink - is being affirmed and deployed as a brand, emerging naturally from the characteristics of particular islands and regions within countries (Helgadottir, 2011; Santich, 2002). There has been a veritable "explosion of interest in 're-localised' and 're-connected' modes of food provision worldwide" (Kneafsey, 2010, p. 177). This intimacy extends not only to the specific place from where the product is derived, but also to other dimensions of traceability: the specific village, farm, field and farmer or fisher from whom and where it was harvested. The very definition and expectation of place have changed. A material rendition and articulation of this burst of locality are the drive to authenticate food and drink that is associated with distinct regions, as with the DOC (Denominazione di Origine Controllata) appellation. Thus, a sub-national geographical origin has become a key selling point of a product and prevents cheaper substitutes originating from elsewhere from being made available to the customer. Important to these places that are also islands is the notion of an exclusive remoteness and an island magic. To the core of this millenary, "island lure" (Lockhart, 1997) belongs the idea of a certain "terroir", a marker of exclusivity, stressing typicality and originality in place (Gyimóthy \& Mykletun, 2009, p. 260), Such appellations are now part of the core rural tourism experience: they offer a distinct local flavour to the food, beer, wine and other spirits available (Baldacchino, 2010; also Aurier, Fort, \& Sirieix, 2005).

The third justifiable explanation for the contemporary fascination with food is transnational compatibility. All places are different, and their uniqueness is increasingly celebrated given the twin movements of glocalisation and regionalisation. And yet, the way in which locality is produced and manifested in multiple locations is strangely similar. This phenomenon may have much to do with the expanding tourist industry and its powerful demonstration effect. Back in the 1970s and 1980s, European holiday-makers who spent their summer holidays in places such as Spain, France, Italy and Greece, Australians who descended on Bali and Soviets who flocked to the Black Sea, all enjoyed a variety of "local specialties" in local restaurants. Returning back home, or heading off to different tourism destinations, these holiday-makers would ask for and expect "local specialities", and supply quickly gets its act together to meet untapped demand. There are now local fiestas, harvest festivals and taste villages that are eyeing the tourist market all over the world, and typically organised around the tourism shoulder season (Löfgren, 1999, p. 189). Again, back to our Gotland example: while lamb steak provided a good and hearty main course, the saffron pancake made a delicious companion. It was the perfect local dessert; exotic, endemic, islandic and Gotlandic.

Fourth is the transformation of the mature tourism industry into one that is increasingly presenting itself as experience (rather than product) driven, and allegedly looking for the (more) authentic. Local food can play an important role in sustainable rural tourism because it appeals to the visitor's desire for authenticity within the holiday experience (Sims, 2009). The paradox of "staged authenticity" has long been acknowledged in the critical anthropology of tourism (MacCannell, 1973). With economies and 
communities gearing up their act to satisfy heavy tourism demand all over the world, and doing so in unsurprisingly similar ways, the hunt is on for more intimate, more genuine encounters and experiences; and of course the locals will try to oblige, creating antechambers for special interactions with select guests, while at the same time using elaborate "fencing strategies" (via the resort of local languages, for instance) to keep visitors out of some personal and communal spaces (Boissevain, 1996). Opportunities for eating and drinking provide such (but nevertheless often deep-acted) windows of authenticity (Van Dijk, Smith, \& Cooper, 2011). Furthermore, the multi-sensorial experience of eating and drinking "functions as a personal source of information, for the stories people and tourists tell about their lives [and their travels] are important for their self-perception" (Mehmetoglu \& Engen, 2011, p. 237). Some of this performativity is mobile and exportable: think of the Irish Pub, now a global phenomenon that creates the ambience of a national fantasy that clients can enjoy, allowing them to fantasise that this is what being Irish must be like (Munoz, Wood, \& Solomon, 2006).

Fifth is another modern love affair: that with healthy living. The thrust for living longer and healthier lives, and the obsession with the body and its image, takes many forms, and has spawned a complex industry: from massage parlours and saunas to gyms and health spas, and from diet regimens to organic foods. The high quality of "good food" is increasingly expected and demanded, and not just appreciated, by locals and tourists alike. The "stable to table" dynamic (already referred to above) allows a connection, albeit subtle and elusive, between the burgeoning urban consumer mass market and the imagined rural idyll of petty commodity production that feeds and nourishes it. Various societies - small island societies, by and large are heralded and advertised as harbouring the secret of long life: these include Dominica, Ikaria (Greece) and Okinawa (Japan) (Anthony, 2013; Booth, 2013; Whitford, 2012). This condition may well have to do with what the locals eat and drink. By the turn of the twenty-first century, a prominent idea in circulation is that the Mediterranean diet, rich in fish, vegetables and olive oil, is far healthier than those bland Northern European diets based on beef or pork and potatoes. Like the search for the mythical elixir of eternal life, the quest for the just-as-elusive perfect diet goes on.

And, last but not least, there is the, often vicarious, urge to (re)connect with nature. This is perhaps the trend that has most potential for uplifting rural economies. There is a widespread sensibility that not only technology, tarmac and concrete, but also McWorld, genetically modified crops and agribusiness have alienated and cheated us from our roots and material identity. Opportunities to connect with nature - ironically, through a consumptive and appropriative visual gaze from the comfort and security of one's home - explain the popularity of National Geographic channels on TV, as well as the attractiveness of adopt-a-tree or animal fund-raising campaigns (Parameswaran, 2002). Moreover, there is growing awareness that produce gets unsustainably shipped over enormous distances to satisfy diverse consumer tastes in far-flung supermarkets. One powerful initiative in response to these supply logistics has been to support "food security" and buy "slow food", made from wholesome ingredients that are sourced or farmed locally, and in a sustainable manner, within, say, a 100-kilometre radius of the consumer (Andrews, 2008; Jones, Shears, Hillier, Comfort, \& Lowell, 2003). Most food activist discourses make a strong connection between the localisation of food systems, the notion of appropriate technology and the promotion of 
environmental sustainability and social justice (DuPuis, \& Goodman, 2005; Nabhan, 2002; Schumacher, 2010).

\section{But It Does Not All Taste Good: Digesting the Difficulties.}

These six distinct but inter-connected trends offer solutions not only to some of the pressing socio-economic and environmental problems associated with food production and consumption of our time, but also to the challenges of maintaining viable small and peripheral economies. Niche market strategies, supported by carefully leveraged and crafted brands, build recognition and consumer loyalty, hopefully generating lifelines to tourist and other external markets for the food, drink and other tangible and/or intangible products of small and marginalised communities. They also create sustainable jobs at home, reducing the inevitability of rural, often youth, outmigration. Meanwhile, the "quality of life" attractions of these same rural milieus puts them on the radar of growing numbers of urban and lifestyle refugees, who are willing and able to escape, albeit temporarily, to indulge in "the good life" and contribute to growing the local rural population (O’Reilly, \& Benson, 2009).

This appears to be all good news: to communities, consumers, economies, local producers, suppliers and workers. And yet, there are some dark clouds on the horizon, because the story of food remains also an intrinsic facet of power and privilege. A more nuanced understanding of who actually gains, and who loses, from the contemporary food fad is warranted. Indeed, with a history of industrial capitalism shuttling between the extremes of protectionism and market liberalisation, a clear and disturbing politics of food emerges when the pendulum approaches either pole (Friedmann, 1995, p. 15).

First, and as expressions of global market dominance, is the clever strategic positioning of large food and drink producers. One should not be surprised that big corporations recognise a threat - as well as an opportunity - when they see one, and take appropriate action. And here, the reaction to a successful local product could include a leveraged buyout, a price war that forces the local producer out of business, or the production of what are presented as "local" products - such as beer - that are actually part of a repertoire of brands owned by bigger firms (Baldacchino, 2010). The larger, global corporate businesses cannot be discounted from venturing into niche markets. They have the ability to develop specialised designer products that seek to appeal to specific market niches, posing a real threat to local fare. Indeed, many so-called local products are produced elsewhere; others, while produced locally, may be owned by off-island companies, and so are less local than they appear. Thus, "Fiji Water", while containing water bottled in Fiji, is owned by an American couple (Connell, 2006; Kaplan, 2007). Global firms have come to know and appreciate the value of locality: whether it is AnheuserBusch InBev (one of the world's largest beer brewers) or HSBC (one of the world's largest banks), being a "local brewer" or a "local bank" has long been part of their respective tag line, and one that these two firms have decided to mutually respect (AB InBev, 2003).

Second, and in response, as an expression of the dangers of excessive protection against market forces, are the real risks of monopoly or oligopoly status achieved by local producers, breeding inefficiencies and eroding or eliminating competitive 
pressures. These result in a reduced choice of goods that are usually of lower quality as well as more expensive. Producing local products to satisfy loyal local and/or tourist demand can take consumers for a ride, just because the buyers come across as an easy, sympathetic, protectionist-friendly and perhaps even a not-too-demanding captive market. Price and product competition is less prevalent in small and remote markets, where bigger players may not be interested in staking a presence. A single producer or processor may dominate the market, and effectively set prices. Local cartels whether in production, in processing, in merchandise trade or in combinations of these - may well explain why local products or services in small and remote rural and island communities are more expensive than on the mainland or in the city; transport and delivery costs and diseconomies of scale are not always to blame, though they too can be impacted by a situation of imperfect competition (Armstrong, Johnes, Johnes, \& MacBean, 1993; Gyimóthy \& Mykletun, 2009, p. 265).

Third, what may be marketed as a quaint, rustic, family recipe or dish could very well be produced industrially, and on a large scale. Thus, commodification is not just the consequence of large and external corporate interests driven blindly by profit margins; it could be also self-inflicted. Locals may be quick to denounce the fake appeals for fresh (often frozen) food presented by foreign corporate giants, with a poignant and emotive tag line such as "just like mama used to make": by the way, this phrase is not just one of the world's best known clichés; it is also the name of a cook book (Antinozzi, 2005). But when it comes to local producers, a similar pitch may be tolerated by the locals; indeed, they may be more likely to believe it. Here, success can breed failure: a product that may start off as a traditional, family and handmade recipe may become so successful and generate such demand that the operation becomes commercialised, the local kitchen equipment is replaced with stainless steel components and bulk industrial processes start being applied (Welz \& Andilios, 2004). In the interests of cutting costs as well as to upscale and further romance the brand (Martin, 1989), traditional ingredients that had been sourced locally may start being imported from elsewhere, and even replaced by trendier fare: bread replaces breadfruit; aquavit replaces sour milk. Hygiene, occupational safety and animal welfare regulations impose other obligations. Any communal collaborative element and voluntary family labour are typically superceded by private profit seeking and conventional employment relations. Of course, past homely idylls about the making of such a product are likely to persist in its branding and marketing strategies. The main way to beat the urge to grow is to stick stubbornly to tradition, hoping that its allure would allow the product to develop a sense of exclusivity and its own priceinsensitive niche.

Meanwhile, the promise of food and drink in lifting rural and remote communities out of their economic doldrums smacks of the hubris of neo-liberalism. The arguments that speak of the virtues of a culinary renaissance are essentially supply driven; they can easily end up as empty rhetoric if they are not matched by movements on the demand side. The enthusiasm by local residents to produce and showcase unique and tasty local products may have value in itself; of course, this is what communities may want to do anyway, whether in crisis or not, whether tourism-focussed or not. However, specific initiatives that are driven by hopes of catalysing local economic development may not last long unless people turn up to taste, enjoy and pay up. And, in spite of the 
wide support it enjoys from all sides, the practice of entrepreneurship remains a zerosum game unless it is accompanied by economic growth. The adage "build it and they will come" does not always work in the real world; and especially in rural tourism, where "substantial marketing is necessary to make a destination known and attractive, both to the general public and to commercial gatekeepers such as travel agents" (Cohn, 2007, p. 12). And that is just the beginning.

\section{Romancing the Brand, and the Bland}

None of the 80 or so contributors to the $A$ Taste of Islands book project flagged any of these concerns. When asked to write about a local dish, even academics can perhaps be excused from not being as diligently critical and reflexive as they usually are in their professional work. Nationalism, and its usage as a hook to attract potential tourist revenue, remains a powerful force, even among scholars who are expected to be critical. An irresistible obligation to champion the national or regional narrative kicks in. Perhaps even unwittingly, one tends to somewhat romance the subject matter to present a particular version of "local history". This is:

... a narrative that pleases by offering the reader soothing notions of happy families, healthy eating, resilient island communities, and much togetherness and comradeship. All histories are partial, and always subjective and symbolic. There is no such thing as a definitive version of the past, or the present, and many of the essays in this book share this preference for concocting a particularly bucolic, enticing, perhaps even exotic representation of their island home or research site. And so it might very well be. (Baldacchino \& Baldacchino, 2012, p. 9)

\section{Crafting the Distinctly Local}

In an age of data overload, we are continually accosted by multiple signals vying for our attention, and hoping to elicit a particular set of responses in us; food can perhaps stand out from the noise, attract clientele, get people visiting restaurants and appreciating ingredients, but also noting and acknowledging their supporting locales and nurturing cultures. In a situation where millions need to be fed, and on a regular basis - the human stomach is ideally supplied every six hours or so - the commercialisation of food is a major economic activity, a political headache and a spur for social activism. And in a situation of rural population decline and youth outmigration, and with tourism as a beckoning magic remedy to economic stagnation, the romancing of food as tangible and emblematic culture yet tradable commodity in the context of a rural development strategy is an obvious and tempting consideration that suggests only positive sum gains. We have suggested in this paper that this optimism needs to be tempered.

While different locales would wish to highlight the particular specialities of their respective region, the standard recipe for doing so follows a simple protocol. Just a few easy steps need to be followed: 
- Start with some basic local ingredients, preferably ones that easily lend themselves to a deep historicity, and even better if they have a connection to a specific and interesting historical detail or human episode: nothing beats a good story or a memorable character. If these ingredients have lost, or do not yet have, a gripping yarn, well, that can always be arranged.

- Throw in, for good measure, a cooking technique that is relatively simple to follow and will not make your audience's eyes glaze over. Indeed, take this as an opportunity to showcase local cooking procedures, utensils, rituals and tips.

- Spice the whole process with some key and poignant language - "must" words include authentic, grandmother, wholesome, frugal, rustic, genuine, time-honoured, handed down from generation to generation ... In this way, the audience feels that it has the distinct honour and privilege of tapping, and being inducted, into a rich, exclusive and revered tradition. (By the way, this initiation may not always be suitable for the faint-hearted: for example, think rotten shark and brennivín in Iceland.)

- Add a dash of mystery by referring to a secret ingredient, a clever addition by a wise cook sometime in the past, or avoiding precise information about how much of certain ingredients to include...just enough to make the exact reproduction of the dish next to impossible. Taboos, protocols, charms, spells and other nuances can also be added as part of the magic.

- Garnish with mouth-watering images, evocative smells and be ready to serve.

Such efforts at "romancing the brand" (Martin, 1989) at the marketing end are considerable. We are here immersed in the operations of an industry that sees its success as based on an enticing and convincing "invention of tradition": a concept initially proposed to describe the emergence of nations, but now extended to cover all products that are meant to have a deep historical, cultural or territorial connection (Hobsbawm \& Ranger, 2012).

\section{Conclusion}

Our humble local cuisine is not so lowly and unassuming any more. Indeed, it is now burdened with very high expectations; and some are bound to remain unfulfilled. Whether it is the private kitchen or the public food market, these are the contemporary sites of contestation in the construction of identity, memory and nationalism, and of local culture more generally. The road towards a viable rural development strategy is fraught with good intentions as well as mouth-watering offerings.

This is not to dismiss the promise of food tourism. Demand is growing and perhaps the main challenge to rural tourism operators is whether they can resist the urge to stay small, or stay local, as demand picks up and opportunities for growth emerge. Much like so many other parts of the world that have tapped, deliberately or otherwise, into the growing tourism industry, the broad North Atlantic offers a rich but recent history in the construction of tradition, and food (and drink) occupies a key position in this development. This paper has hopefully rescaled these developments by locating them on a broader canvas, shedding light on processes that are often less visible and thus less subject to critique; food for thought, one hopes. 


\section{Disclosure statement}

No potential conflict of interest was reported by the author.

\section{References}

AB InBev. (2003, April 8). Mutual acknowledgement of respective corporate slogan rights by HSBC and Interbrew. Retrieved from http://www.ab-inbev.com/go/media/global_press_releases/press_release. cfm?theID $=167$ \& theLang $=\mathrm{EN}$

Andrews, G. (2008). The slow food story: Politics and pleasure. London: Pluto Press.

Anthony, A. (2013, May 31). The island of long life. The Guardian. Retrieved from http://www. theguardian.com/world/2013/may/31/ikaria-greece-longevity-secrets-age

Antinozzi, L. (2005). Just like mama used to make: Recipes and traditions from an Italian kitchen. London: Cassell.

Armstrong, H. W., Johnes, G., Johnes, J., \& MacBean, A. (1993). The role of transport costs as a determinant of price level differentials between the Isle of Man and the United Kingdom. World Development, 21(2), 311-318. doi:10.1016/0305-750X(93)90026-6

Aurier, P., Fort, F., \& Sirieix, L. (2005). Exploring terroir product meanings for the consumer. Anthropology of Food 4. Retrieved from http://aof.revues.org/187

Baldacchino, A., \& Baldacchino, G. (Eds.). (2012). A taste of islands: 60 recipes and stories from our world of islands. Charlottetown, PE: Island Studies Press.

Baldacchino, G. (2010). Islands and beers: Toasting a discriminatory approach to small island manufacturing. Asia Pacific Viewpoint, 51(1), 61-72. doi:10.1111/j.1467-8373.2010.01414.x

Barry, D. (2005). Icy battleground: Canada, the international fund for animal welfare and the seal hunt. St. John's, NL: Breakwater Books.

Bogadottir, R. (2012). Fish ball soup/Knettasupan. In A. Baldacchino \& G. Baldacchino (Eds.), A taste of islands: 60 recipes and stories from our world of islands (pp. 12-15). Charlottetown, PE: Island Studies Press.

Boissevain, J. (1996). Coping with tourists: European reactions to mass tourism. New York: Berghahn Books.

Boon, B. (2007). Working within the front-of-house/back-of-house boundary: Room attendants in the hotel guest room space. Journal of Management and Organisation, 13(2), 160-174.

Booth, M. (2013, June 19). The Okinawa diet: Could it help you live to 100? The Guardian. Retrieved from http://www.theguardian.com/lifeandstyle/2013/jun/19/japanese-diet-live-to-100

Bourdieu, P. (1984). Distinction: A social critique of the judgement of taste. Cambridge, MA: Harvard University Press.

Cohen, E., \& Avieli, N. (2004). Food in tourism: Attraction and impediment. Annals of Tourism Research, 31(4), 755-778. doi:10.1016/j.annals.2004.02.003

Cohn, S. (2007, August). State led development, debt and democracy: How Brazil almost created a vibrant tourist economy. Paper presented at annual meeting, American Sociological Association, New York. Retrieved from http://195.130.87.21:8080/dspace/bitstream/123456789/618/1/State\%20led\%20deve lopment $\% 2 \mathrm{c} \% 20$ debt $\% 20$ and $\% 20$ democracy $\% 20$ how $\% 20$ Brazil\%20almost $\% 20$ created $\% 20 \mathrm{a} \% 20 \mathrm{vib}$ rant\%20tourist\%20economy.pdf

Connell, J. (2006). The taste of paradise: Selling Fiji and Fiji water. Asia Pacific Viewpoint, 47(3), $342-$ 350. doi:10.1111/j.1467-8373.2006.00310.x

DuPuis, E. M., \& Goodman, D. (2005). Should we go 'home' to eat? Toward a reflexive politics of localism. Journal of Rural Studies, 21(3), 359-371. doi:10.1016/j.jrurstud.2005.05.011

European Commission. (2012). EU biodiversity strategy to 2020: Towards implementation. Retrieved from http://ec.europa.eu/environment/nature/biodiversity/comm2006/2020.htm

Fielding, R. (2010). Environmental change as a threat to the pilot whale hunt in the Faroe Islands. Polar Research, 29(3), 430-438. doi:10.1111/j.1751-8369.2010.00168.x

Friedmann, H. (1993). The political economy of food: A global crisis. New Left Review, No. 197, pp. $29-57$.

Friedmann, H. (1995). Food politics: New dangers, new possibilities. In P. MacMichael (Ed.), Food and agrarian orders in the world economy (pp. 15-33). Westport, CT: Praeger. 
Griessner, D. (2012). Åland pancake/Ålandspannkaka. In A. Baldacchino \& G. Baldacchino (Eds.), A taste of islands: 60 recipes and stories from our world of islands (pp. 224-227). Charlottetown, PE: Island Studies Press.

Griggio, C. (2012). Roe Pancakes/Rognkake. In A. Baldacchino \& G. Baldacchino (Eds.), A taste of islands: 60 recipes and stories from our world of islands (pp. 248-251). Charlottetown, PE: Island Studies Press.

Gutsy Gourmet. (2013). The national dish. Retrieved from http://www.thegutsygourmet.net/national-dish. html

Gyimóthy, S., \& Mykletun, R. J. (2009). Scary food: Commodifying culinary heritage as meal adventures in tourism. Journal of Vacation Marketing, 15(3), 259-273. doi:10.1177/1356766709104271

Hawkes, J. G., \& Francisco-Ortega, J. (1993). The early history of the potato in Europe. Euphytica, $70(1-$ 2), 1-7. doi:10.1007/BF00029633

Helgadottir, G. (2011). Nation in a sheep's coat: The Icelandic sweater. FORMakademisk, 4(2). Retrieved from https://journals.hioa.no/index.php/formakademisk/article/view/201

Hobsbawm, E., \& Ranger, T. (Eds.). (2012). The invention of tradition. Cambridge: Cambridge University Press.

Holbrook, M. B., \& Hirschman, E. C. (1982). The experiential aspects of consumption: Consumer fantasies, feelings, and fun. Journal of Consumer Research, 132-140. doi:10.1086/208906

Jones, P., Shears, P., Hillier, D., Comfort, D., \& Lowell, J. (2003). Return to traditional values? A case study of Slow Food. British Food Journal, 105(4/5), 297-304. doi:10.1108/00070700310477095

Jónsson, O. D. (2012). Flat bread and mutton paté / Flatbrauð með kindakæfu. In A. Baldacchino \& G. Baldacchino (Eds.), A taste of islands: 60 recipes and stories from our world of islands (pp. 60-63). Charlottetown, PE: Island Studies Press.

Kaplan, M. (2007). Fijian water in Fiji and New York: Local politics and a global commodity. Cultural Anthropology, 22(4), 685-706. doi:10.1525/can.2007.22.4.685

Kneafsey, M. (2010). The region in food: Important or irrelevant? Cambridge Journal of Regions, Economy and Society, 3(2), 177-190. doi:10.1093/cjres/rsq012

Korsmeyer, C. (2002). Delightful, delicious, disgusting. Journal of Aesthetics and Art Criticism, 60(3), 217-225. doi:10.1111/1540-6245.00069

Lockhart, D. G. (1997). Tourism and islands: An overview. In D. G. Lockhart \& D. Drakakis-Smith (Eds.), Island tourism: Trends and prospects (pp. 3-20). London: Pinter.

Löfgren, O. (1999). On holiday: A history of vacationing. Berkeley: University of California Press.

MacCannell, D. (1973). Staged authenticity: Arrangements of social space in tourist settings. American Journal of Sociology, 79(3), 589-603. doi:10.1086/225585

Malm, T. (2012). Filled potato dumplings/Kroppkakor. In A. Baldacchino \& G. Baldacchino (Eds.), A taste of islands: 60 recipes and stories from our world of islands (pp. 56-59). Charlottetown, PE: Island Studies Press.

Martin, D. N. (1989). Romancing the brand: The power of advertising and how to use it. New York: Amacom.

Marx, K. (1959/1973). Grundrisse: Introduction to the critique of political economy. Baltimore, MA: Penguin Books.

Mehmetoglu, M., \& Engen, M. (2011). Pine and Gilmore's concept of experience economy and its dimensions: An empirical examination in tourism. Journal of Quality Assurance in Hospitality \& Tourism, 12(4), 237-255. doi:10.1080/1528008X.2011.541847

Munoz, C. L., Wood, N. T., \& Solomon, M. R. (2006). Real or blarney? A cross-cultural investigation of the perceived authenticity of Irish pubs. Journal of Consumer Behaviour, 5(3), 222-234. doi:10.1002/cb.174

Nabhan, G. P. (2002). Coming home to eat: The pleasures and politics of local foods. New York: WW Norton.

Olsen, N. L. (2012). Halibut soup/Nerpilaat. In A. Baldacchino \& G. Baldacchino (Eds.), A taste of islands: 60 recipes and stories from our world of islands (pp. 26-29). Charlottetown, PE: Island Studies Press.

O'Reilly, K., \& Benson, M. (2009). Lifestyle migration: Escaping to the good life? In M. Benson \& K. O'Reilly (Eds.), Lifestyle migrations: Expectations, aspirations and experiences (pp. 1-13). Farnham: Ashgate.

Parameswaran, R. (2002). Local culture in global media: Excavating colonial and material discourses in National Geographic. Communication Theory, 12(3), 287-315. doi:10.1111/j.1468-2885.2002.tb00271.x 


\section{G. Baldacchino}

Parsons, E. C. M., \& Rawles, C. (2003). The resumption of whaling by Iceland and the potential negative impact in the Icelandic whale-watching market. Current Issues in Tourism, 6(5), 444-448. doi:10. 1080/13683500308667964

Pollan, M. (2013). Cooked: A natural history of transformation. New York: Penguin.

Ratter, B. W. (2012). Rock crab/Knieper. In A. Baldacchino \& G. Baldacchino (Eds.), A taste of islands: 60 recipes and stories from our world of islands (pp. 186-189). Charlottetown, PE: Island Studies Press.

Raviv, Y. (2003). Falafel: A national icon. Gastronomica: The Journal of Critical Food Studies, 3(3), 2025. doi:10.1525/gfc.2003.3.3.20

Roach, M. (2013). Gulp: Adventures on the alimentary canal. New York: WW Norton.

Ronström, O. (2012). Saffron pancake/Saffranspankakka. In A. Baldacchino \& G. Baldacchino (Eds.), $A$ taste of islands: 60 recipes and stories from our world of islands (pp. 252-255). Charlottetown, PE: Island Studies Press.

Santich, B. (2002). Regionalism and regionalisation in food in Australia. Rural Society, 12(1), 5-16. doi:10.5172/rsj.12.1.5

Schumacher, E. F. (2010/1973). Small is beautiful: Economics as if people mattered. New York: Harper Perennial.

Sims, R. (2009). Food, place and authenticity: Local food and the sustainable tourism experience. Journal of Sustainable Tourism, 17(3), 321-336. doi:10.1080/09669580802359293

Springuel, N. (2011). Tourism in regions of natural resource decline: A Newfoundland case study. Tourism in Marine Environments, 7(3-4), 179-190. doi:10.3727/154427311X13195453162895

Stephens, J. (2012). Boxty pancakes. In A. Baldacchino \& G. Baldacchino (Eds.), A taste of islands: 60 recipes and stories from our world of islands (pp. 48-51). Charlottetown, PE: Island Studies Press.

Sutton, D. (2001). Remembrance of repasts: An anthropology of food and memory. New York: Berg.

Sutton, J. (2012). Fish chowder. In A. Baldacchino \& G. Baldacchino (Eds.), A taste of islands: 60 recipes and stories from our world of islands. (pp. 18-21). Charlottetown, PE: Island Studies Press.

Tellström, R., Gustafsson, I., \& Mossberg, L. (2006). Consuming heritage: The use of local food culture in branding. Place Branding, 2(1), 130-143. doi:10.1057/palgrave.pb.5990051

Thomas, E. B. (2012). Lobster scallop newberg. In A. Baldacchino \& G. Baldacchino (Eds.), A taste of islands: 60 recipes and stories from our world of islands (pp. 146-149). Charlottetown, PE: Island Studies Press.

Tita, G., Theriault, G., \& Langford, C. (2012). Seal fat fried donuts/Croxignoles. In A. Baldacchino \& G. Baldacchino (Eds.), A taste of islands: 60 recipes and stories from our world of islands (pp. 256-259). Charlottetown, PE: Island Studies Press.

Tucci, S., Powell, J., Child, J., \& Prud'homme, A. (2010). Julie \& Julia. Culver City, CA: Sony Pictures Home Entertainment.

Tye, D. (2012). 'Jigg's dinner'. In A. Baldacchino \& G. Baldacchino (Eds.), A taste of islands: 60 recipes and stories from our world of islands (pp. 134-137). Charlottetown, PE: Island Studies Press.

Van Dijk, P. A., Smith, L. D., \& Cooper, B. K. (2011). Are you for real? An evaluation of the relationship between emotional labour and visitor outcomes. Tourism Management, 32(1), 39-45. doi:10.1016/j. tourman.2009.11.001

Welcome to Smakbyn! (2014). Retrieved from http://smakbyn.ax/en

Welz, G., \& Andilios, N. (2004). Modern methods for producing the traditional: The case of making halloumi cheese in Cyprus. In P. Lysaght \& C. Burckhardt-Seebass (Eds.), Changing tastes. Food culture and the processes of industrialization (pp. 217-230). Dublin: The Department of Irish Folklore, University College Dublin. Retrieved from http://www.uni-frankfurt.de/fb/fb09/kulturanthro/ documents/Welz-Andilios_Modern_Methods_for_Producing_the_Traditional.pdf

Whitford, G. M. (2012, March 19). 'Ma Pampo' and the centenarians of Dominica. Retrieved from http:// gwenithwhitford.wordpress.com/2012/03/19/ma-pampo-and-the-centenarians-of-dominica-2/ 